\title{
KUAT TEKAN BETON AWAL TINGGI DENGAN VARIASI PENAMBAHAN SUPERPLASTICIZER DAN SILICA FUME
}

\section{HIGH EARLY AGE CONCRETE COMPRESSIVE STRENGTH WITH VARIATION SUPERPLASTICIZER AND SILICA FUME}

\author{
Hakas Prayuda ${ }^{1}$, Fadillawaty Saleh $^{2}$ \\ ${ }^{1,2}$ Program Studi Teknik Sipil-Fakultas Teknik-Universitas Muhammadiyah Yogyakarta \\ Jl. Lingkar Selatan, Tamantirto, Kasihan, Bantul, Yogyakarta, 55183 \\ email: hakasprayuda@umy.ac.id ; dilla_vu@yahoo.com
}

\begin{abstract}
Concrete is one of the construction materials of combination between cement, fine aggregate, coarse aggregate, and water mixed into one solid mass. The work of concrete making can be added a mineral additive as well as chemical additive (admixture) for the interest in construction work. In some cases construction work is desirable for concrete to produce optimum strength during the early age of the concrete so that the timing of concreting work can be shortened. The strength of concrete at the early age can be increased with added mineral (additive) and chemical (admixture) materials. This research made a mixture of concrete with 7 variations of mixture with total specimen 54 sample of cylindrical size with diameter $15 \mathrm{~cm}$ and height $30 \mathrm{~cm}$. Tests conducted in the form of testing workability and compressive strength of concrete at the age of 3 days, 7 days and 28 days. Through this study obtained the right composition to make concrete with a high early age of compressive strength.
\end{abstract}

Keywords: Compressive Strength; High Early Age; Silica Fume; Superplasticizer

\begin{abstract}
Abstrak
Beton merupakan salah satu bahan konstruksi hasil kombinasi antara semen, agregat halus, agregat kasar, dan air yang dicampur menjadi satu massa padat. Pekerjaan pembuatan beton dapat ditambahkan suatu bahan tambah mineral (additive) maupun bahan tambah kimiawi (admixture) guna kepentingan dalam pekerjaan konstruksi. Pada beberapa kasus pekerjaan konstruksi diinginkan agar beton yang dapat dihasilkan kekuatan yang optimum pada umur awal beton sehingga waktu pengerjaan pembetonan dapat dipersingkat. Kekuatan beton pada umur awal dapat ditingkatkan dengan bahan tambah mineral (additive) maupun kimia (admixture). Penelitian ini membuat campuran beton dengan 7 variasi campuran dengan total benda uji 54 sampel berukuran silinder dengan diameter $15 \mathrm{~cm}$ dan tinggi $30 \mathrm{~cm}$. Pengujian yang dilakukan berupa pengujian workability dan kuat tekan dari beton pada umur 3 hari, 7 hari dan 28 hari. Melalui penelitian ini diperoleh komposisi yang tepat untuk membuat beton dengan kuat tekan awal tinggi
\end{abstract}

Kata kunci: Kuat Tekan; Awal Tinggi; Silica Fume; Superplastisizer

\section{PENDAHULUAN}

Beton merupakan salah satu material konstruksi yang sudah umum digunakan di mana berbahan dasar menggunakan semen, agregat kasar, agregat halus dan air yang dicampur sedemikian rupa berdasarkan perkiraan yang telah dihitung menjadi material padat seperti batuan. Beberapa keuntungan dari penggunaan beton sebagai material konstruksi antara lain mudah dalam pembuatan dan pengerjaannya, menggunakan bahan baku yang sangat mudah diperoleh serta taham terhadap api dan waktu. Pengaplikasian pembuatan beton dilapangan biasanya menggunakan tulangan baja yang kemudian biasa di sebut beton bertulang.

Proses pembuatan beton konvensional membutuhkan waktu yang cukup lama dibandingkan dengan material lainnya serta membutuhkan bekisting untuk meletakkan beton segar. 
Pengecoran dilakukan minimal dalam waktu satu hari yang kemudian harus menunggu beton berumur 7 hari yang kemudian bekisting dapat dibongkar dan dilakukan pekerjaan selanjutnya. Lamanya waktu proses pengerjaan ini dan menunggu kekuatan beton di batas aman untuk lakukan pengerjaan berikutnya membuat seringkali proyek konstruksi lebih lama masa pengerjaan nya.

Melalui permasalahn tersebut, dilakukanlah analisis variasi campuran beton dengan tujuan untuk menghasilkan kekuatan di awal yang cukup tinggi dengan harapan, dapat membantu percepatan pengerjaan proyek konstruksi yang bermaterial dasar dari beton. Menghasilkan beton dengan kekuatan awal tinggi dapat mempercepat proses pembongkaran bekisting serta dengan cepat dapat melanjutkan pekerjaan ke tahap berikutnya.

Pada penelitian ini menganalisis kuat tekan beton yang terdiri dari variasi superplastisizer dan silica fume. Analisis yang dilakukan berupa kuat tekan silinder beton pada umur 3, 7 dan 28 hari. Total benda uji pada penelitian ini sebanyak 54 benda uji berukuran diameter $15 \mathrm{~cm}$ dan tinggi $30 \mathrm{~cm}$ dengan 6 variasi campuran.

Beberapa penelitian mengenai silica fume sebagai bahan pembuatan beton pernah dilakukan Mazloom dkk., (2004) yang menganalisis efek dari penggunaakn silica fume terhadap mekanikal properties pada beton mutu tinggi. Karein dkk., (2017) meneliti mengenai ukuran dari silica fume terhadap kuat tekan beton, dimana ukuran yang dibuat dalam keadaan basah yang dibentuk seperti butiran butiran kecil sesuai dengan masing-masing variasi. Rostami dan Behfarmia (2017) melakukan penelitian mengenai efek dari silica fume terhadap durabilitas alkali aktivator pada beton menggunakan bahan slag. Melalui beberapa penelitian di atas, dapat disimpulkan bahwa silica fume berpotensi untuk meningkatkan kuat tekan awal beton.

Beton dengan kuat tekan awal tinggi, pada dasarnya bukanlah teknologi yang baru didunia konstruksi, akan tetapi sampai dengan saat ini, belum melalui penelitian ini diharapkan dapat memperoleh komposisi yang tepat untuk mendapatkan beton dengan kuat tekan awal yang cukup baik untuk mempercepat pekerjaan konstruksi. Bhalla dkk., (2018) melakukan penelitian mengenai monitoring kuat tekan awal beton berbahan tambah silica fume menggunakan metode wave propagation, melalui penelitian ini menghasilkan kuat tekan beton pada umur 3 hari sebesar 15 MPa. Shen, dkk., (2016) melakukan penelitian mengenai hubungan andara modulus tarik dan tekan beton dengan kuat tekan awal tinggi menggunakan bahan tam,bah fly ash.

\section{Kuat Tekan Beton}

Beton adalah campuran dari agregat halus dan kasar (pasir, kerikil, batu pecah atau jenis agregat lain) dengan semen, yang dipersatukan oleh air dalam perbandingan tertentu (Samekto dan Rahmadiyanto, 2001). Berdasarkan (BSN, 2000) beton didefinisikan sebagai campuran antara semen portland atau semen hidraulik yang lain, agregat halus, agregat kasar dan air dengan atau tanpa bahan tambah membentuk massa padat.

Kekuatan tekan beton akan bertambah dengan naiknya umur beton. Kekuatan beton akan naiknya secara cepat (linier) sampai umur 28 hari, tetapi setelah itu kenaikannya akan kecil. Kekuatan tekan beton pada kasuskasus tertentu akan bertambah sampai beberapa tahun dimuka. Biasanya kekuatan rencana beton dihitung pada umur 28 hari. Untuk struktur yang menghendaki kekuatan awal tinggi, maka campuran dikombinasikan dengan semen khusus atau ditambah dengan bahan tambah kimia dengan tetap menggunakan jenis semen tipe I (OPC-I). Laju kenaikan umur beton sangat tergantung dari penggunaan bahan penyusunnya yang paling utama dalah penggunaan bahan semen karena semen cenderung secara langsung memperbaiki kinerja tekannya (Mulyono, 2004).

Beton dengan kekuatan awal tinggi merupakan beton yang memiliki daya tekan awal yang tinggi pada permulaan setelah proses pengikatan terjadi, sehingga dapat segera dilakukan penyelesaian secepatnya. Tipe beton ini biasa digunakan dalam pembuatan bangunan tingkat tinggi, beton pracetak, jalan beton atau jalan raya bebas hambatan, pembetonan di daerah dingin, bandar udara dan bangunan dalam air yang tidak memerlukan ketahanan sulfat. 
Kekuatan tekan merupakan salah satu kinerja utama beton. Kekuatan tekan adalah kemampuan beton untuk menerima gaya tekan persatuan luas. Walaupun dalam beton terdapat tegangan tarik yang kecil, diasumsikan bahwa semua tegangan tekan didukung oleh beton tersebut (Mulyono, 2004).Berdasarkan BSN (1990) kuat tekan beton adalah besarnya beban per satuan luas, yang menyebabkan benda uji beton hancur bila dibebani dengan gaya tekan tertentu, yang dihasilkan oleh mesin tekan. Besar nilai kuat tekan didapatkan dari hasil bagi beban maksimum hasil uji tekan dengan luas penampang benda uji silinder seperti yang tertulis pada Persamaan 1.

Kuat Tekan Beton $=\frac{P}{A}\left(\frac{\mathrm{kg}}{\mathrm{cm}^{2}}\right)$

dengan:

$\mathrm{P}=$ beban maksimum $(\mathrm{kg})$

$\mathrm{A}=$ luas penampang $\left(\mathrm{cm}^{2}\right)$

Kuat Tekan beton diwakili oleh tegangan maksimum fc' dengan satuan $\mathrm{kg} / \mathrm{cm}^{2}$ atau MPa. Nilai Kuat tekan beton umumnya relatif lebih tinggi dibandingkan dengan kuat tariknya, oleh karena itu untuk meninjau mutu beton biasanya secara kasar hanya ditinjau kuat tekannya saja (Tjokrodimuljo, 2007). Berdasarkan kuat tekannya beton dapat dibagi beberapa jenis sebagaimana terdapat pada Tabel 1 .

Tabel 1. Beberapa jenis beton menurut kuat tekan (Tjokrodimuljo, 2007)

\begin{tabular}{lc}
\hline \multicolumn{1}{c}{ Jenis Beton } & Kuat Tekan \\
\hline Beton sederhana & $<10 \mathrm{MPa}$ \\
Beton normal & $15-30 \mathrm{MPa}$ \\
Beton prategang & $30-40 \mathrm{MPa}$ \\
$\begin{array}{l}\text { Beton kuat tekan tinggi } \\
\text { Beton kuat tekan sangat } \\
\text { tinggi }\end{array}$ & $>80-80 \mathrm{MPa}$ \\
\hline
\end{tabular}

Menurut Pertiwi (2011) besarnya kuat tekan beton dipengaruhi oleh sejumlah faktor antara lain seperti berikut ini.

1. Faktor air semen. Hubungan faktor air semen dan kuat tekan beton secara umum adalah bahwa semakin rendah nilai faktor air semen, semakin tinggi kuat tekan betonnya. Namun kenyataannya, pada suatu nilai faktor air semen semakin rendah, maka beton semakin sulit dipadatkan. Dengan demikian, ada suatu nilai faktor air semen yang optimal dan menghasilkan kuat tekan yang maksimal.

2. Jenis semen dan kualitasnya mempengaruhi kekuatan rata-rata dan kuat batas beton.

3. Jenis dan lekuk-lekuk (relief) bidang permukaan agregat. Kenyataannya menunjukkan bahwa penggunaan agregat batu pecah akan menghasilkan beton dengan kuat tekan yang lebih besar daripada agregat alami.

4. Efisiensi dari perawatan (curing). Kehilangan kekuatan sampai $40 \%$ dapat terjadi bila pengeringan terjadi sebelum waktunya. Perawatan adalah hal yang sangat pengting pada pekerjaan di lapangan dan pada pembuatan benda uji.

5. Suhu. Pada umumnya kecepatan pengerasan beton bertambah dengan bertambahnya suhu. Pada titik beku kuat tekan akan tetap rendah untuk waktu yang lama.

6. Umur pada keadaan yang normal. Kekuatan beton bertambah dengan bertambahnya umur, tergantung pada jenis semen. Misalnya semen dengan kadar alumina tinggi menghasilkan beton yang kuat hancurnya pada 24 jam, sama dengan semen portland biasa pada 28 hari. Pengerasan berlangsung terus secara lambat sampai beberapa tahun.

\section{METODE PENELITIAN}

\section{Alat dan Bahan Penelitian}

Adapun bahan-bahan yang digunakan dalam penelitian terdapat pada uraian berikut ini.

1. Semen Portland Pozzolan Cement (PCC) dengan merk Gresik kemasan 40 kg yang berfungsi sebagai perekat antar agregat.

2. Agregat halus yang berupa pasir Merapi, Sleman, Yogyakarta yang diambil di Laboratorium Teknologi Bahan Konstruksi, Program Studi Teknik Sipil, Fakultas Teknik Universitas Muhammadiyah Yogyakarta.

3. Agregat kasar berupa kerikil Clereng, Kulon Progo, Yogyakarta yang diambil di Laboratorium Teknologi Bahan Konstruksi, Program Studi Teknik Sipil, Fakultas Teknik, Universitas Muhammadiyah Yogyakarta. 
4. Air bersih yang diambil dari Laboratorium Teknologi Bahan Konstruksi, Jurusan Teknik Sipil, Fakultas Teknik Universitas Muhammadiyah Yogyakarta.

5. Bahan tambah berupa silica fume merek SikaFume produksi PT. SIKA yang berfungsi sebagai filler dan pengganti sebagian semen.

6. Bahan Tambah kimia berupa superplasticizer merek Sikament NN produksi PT. SIKA yang berfungsi sebagai accelerator.

Alat-alat yang digunakan dalam penelitian ini dari pemeriksaan bahan hingga pengujian benda uji, dengan uraian berikut ini.

1. Gelas ukur kapasitas maksimum 1000 mluntuk menakar volume air,

2. Tabung Erlenmeyer dengan merek Pyrex, untuk pemeriksaan berat jenis,

3. Timbangan merek Ohauss dengan ketelitian $\pm 0,1$ gram, untuk mengetahui berat dari bahan-bahan penyusun beton,

4. Saringan dan mesin ayakan, untuk mengetahui gradasi dari agregat halus,

5. Oven, untuk pemeriksaan bahan-bahan yang akan digunakan dalam campuran beton,

6. Sekop, cetok dan talam, untuk menampung dan mengaduk dan menuang adukan beton ke dalam cetakan,

7. Mesin Molen untuk melakukan pencampuran dan pengadukan campuraan benda uji dengan volume lebih besar,

8. Kerucut Abrams, untuk menguji nilai slump beton,

9. Cetakan beton berbentuk silinder dengan ukuran $15 \mathrm{~cm}$ x $30 \mathrm{~cm}$,

10.Mesin uji tekan beton merek Hung Ta, digunakan untuk menguji dan mengetahui nilai kuat tekan dari beton.

\section{Pelaksanaan Penelitian}

Desain penelitian yang dilaksanakan di laboratorium dengan menggunakan benda uji silinder diameter $15 \mathrm{~cm}$ dan diameter $30 \mathrm{~cm}$ dengan 6 variasi campuran beton. Adapun komponen yang di variasikan dalam penelitian ini adalah Bahan tambah adiktif dan admixture yang dapat dilihat pada Tabel 2.Pelaksanaan penelitian dimulai dengan pengumpulan data, pengadaan material, pemeriksaan material, pembuatan mix design kemudian pembuatan benda uji yang dilakukan di Laboratorium Teknologi Bahan Konstruksi, Jurusan Teknik Sipil, Fakultas Teknik, Universitas Muhammadiyah Yogyakarta. Metode yang digunakan dalam penelitian ini berupa metode eksperimental, yaitu metode yang dilakukan dengan percobaan. Pengujian agregat halus dan agregat kasar dilakukan untuk mencapai hasil yang telah ditentukan.

Tabel 2. Komponen variasi Bahan tambah

\begin{tabular}{ccc}
\hline \multirow{2}{*}{ Kode } & \multicolumn{2}{c}{ Bahan Tambah } \\
& Sika Fume $(\%)$ & Sikament NN $(\%)$ \\
\hline SS-A & 0 & 0 \\
SS-B & 3 & 1 \\
SS-C & 6 & 1 \\
SS-D & 10 & 1 \\
SS-E & 6 & 0,5 \\
SS-F & 6 & 1,5 \\
\hline \multicolumn{2}{c}{ Langkah-langkah dalam perhitungan mix }
\end{tabular}

design beton normal berdasarkan pada SNI 03-2834-2000, untuk analisis perhitungan mix design dapat dilihat pada Tabel 3.

Tabel 3. Komposisi campuran beton

\begin{tabular}{ccccccc}
\hline Kode & $\begin{array}{c}\text { Semen } \\
(\mathrm{kg})\end{array}$ & $\begin{array}{c}\text { Pasir Merapi } \\
(\mathrm{kg})\end{array}$ & $\begin{array}{c}\text { Kerikil } \\
\text { Clereng }(\mathrm{kg})\end{array}$ & Air (liter) & \multicolumn{2}{c}{ Kadar Bahan Tambah } \\
Sikament NN (liter) & SikaFume (kg) \\
\hline SS-A & 557,07 & 602,15 & 945,79 & 205,00 & 0,00 & 0,00 \\
SS-B & 540,36 & 602,15 & 945,79 & 205,00 & 5,57 & 16,71 \\
SS-C & 523,65 & 602,15 & 945,79 & 205,00 & 5,57 & 33,42 \\
SS-D & 501,36 & 602,15 & 945,79 & 205,00 & 5,57 & 55,71 \\
SS-E & 523,65 & 602,15 & 945,79 & 205,00 & 2,79 & 33,42 \\
SS-F & 523,65 & 602,15 & 945,79 & 205,00 & 8,36 & 33,42 \\
\hline
\end{tabular}

HASIL DAN PEMBAHASAN

Hasil Pemeriksaan Sifat Agregat
Pemeriksaan sifat agregat halus dilakukan terlenbih dahulu sebelum dilakukan 
pembuatan mix design, adapun hasil pemeriksaan agregat halus dapat dilihat pada Tabel 4. Pengujian yang dilakukan berupa kadar lumpur, gradasi butiran, modulus halus butir, berat jenis, penyerapan air, berat satuan dan kadar air. Pada pemeriksaan ini juga di bandingkan dengan penelitian terdahulu oleh Ikhsan dkk (2016). Berdasarkan hasil terbebut disimpulkan bahwa tidak terdapat perbedaan yang signifikan dari penelitian terdahulu.

Tabel 4. Hasil pemeriksaan agregat halus

\begin{tabular}{llll}
\hline $\begin{array}{l}\text { Jenis Pengujian } \\
\text { Agregat }\end{array}$ & Satuan & \multicolumn{2}{l}{ Hasil Pemeriksaan } \\
Pengujian & $\begin{array}{l}\text { Ikhsandkk } \\
(2016)\end{array}$ \\
\hline Kadar lumpur & $\%$ & 4,97 & 4,53 \\
Gradasi butiran & - & Daerah 2 & Daerah 2 \\
Berat jenis & - & 2,47 & 2,58 \\
Penyerapan air & $\%$ & 9,39 & 0,26 \\
Berat satuan & $\mathrm{g} / \mathrm{cm}^{3}$ & 1,50 & 1,31 \\
Kadar air & $\%$ & 2,98 & 4,57 \\
\hline
\end{tabular}

Pemeriksaan agregat kasar dilakukan untuk mengetahui karakteristik dari material tersebut, agregat yang digunakan berasal dari Clereng, Kulon Progo. Pada pemeriksaan ini diperoleh nilai kadar lumpur, keausan agregat, berat jenis, penyerapan air, berat satuan dan kadar air. Hasil pemeriksaan yang dilakukan dibandingkan dengan pengujian terdahulu seperti pada Tabel 5. Terdapat selisih yang cukup signifikan pada nilai kausan agregat dimana pada pemeriksaan diperoleh nilai $33,33 \%$ sedangkan pada penelitian terdahulu diperoleh nilai $21,36 \%$. Hal ini menunjukkan kualitas agregat pada penelitian terdahulu lebih baik dari pada penelitian ini. Sedangkan kadar lumpur yang diperoleh memiliki nilai yang hampir sama, akan tetapi nilai tersebut sama-sama tidak memenuhi standar batas kadar lumpur yang ditentukan yaitu sebesar $1 \%$.

Dari kedua agregat yang di analisis karakteristiknya, dapat disimpulkan material ini masih padat digunakan sebagai bahan pembuatan beton untuk kuat tekan awal tinggi, hanya saja kadar lumpur pada agregat kadsar tidak emenuhi persyaratan yang ditentukan. Untuk mengatasi masalh tersebut, perlu dilakukan pembersihan terlebih dahulu pada agregat kasar sebelum digunakan. Selain itu, kondisi material sebelum diuji hendaklah diperhatikan dengan seksama, apakah dalahm kondisi kering, basah atau kondisi SSD.

Tabel 5. Hasil pemeriksaan sifat agregat kasar

\begin{tabular}{lccc}
\hline \multicolumn{1}{c}{$\begin{array}{c}\text { Jenis } \\
\text { Pengujian } \\
\text { Agregat }\end{array}$} & Satuan & \multicolumn{2}{c}{ Hasil Pemeriksaan } \\
Pengujian & $\begin{array}{c}\text { Ikhsan dkk } \\
(2016)\end{array}$ \\
\hline $\begin{array}{l}\text { Kadar } \\
\text { lumpur }\end{array}$ & $\%$ & 1,76 & 1,75 \\
$\begin{array}{l}\text { Keausan } \\
\text { agregat }\end{array}$ & $\%$ & 33,67 & 21,36 \\
$\begin{array}{l}\text { Berat jenis } \\
\text { Penyerapa }\end{array}$ & $\mathrm{gr} / \mathrm{cm}^{3}$ & 2,59 & 2,63 \\
$\begin{array}{l}\text { nair } \\
\text { Berat }\end{array}$ & $\%$ & 1,66 & 4,47 \\
satuan & - & 1,61 & 1,55 \\
Kadar air & $\%$ & 0,96 & 0,55 \\
\hline
\end{tabular}

\section{Hasil Pemeriksaan Slump}

Pemeriksaan slump dilakukan untuk menentukan tingkat kemudahan pengerjaan nya, setiap variasi memiliki nilai slump yang berbeda beda. Nilai slump terkecil sebesar $2,35 \mathrm{~cm}$ diperoleh benda uji dengan kode SSA dimana benda uji ini merupakan beton normal tanpa bahan tambah Sikament NN dan SikaFume. Menggunakan bahan tambah Sikament NN sebesar 0,5\% memperoleh nilai slump 4,75 cm, kemudian variasi SS-D dengan kadar Sikament NN 1\% dan Sikafume $10 \%$ memperoleh nilai slump $5,78 \mathrm{~cm}$. Nilai slump tertinggi pada benda uji SS-F sebesar $23,26 \mathrm{~cm}$, hal ini disebabkan penggunaan kadar Sikament NN yang cukup tinggi yaitu sebesar $1,5 \%$.

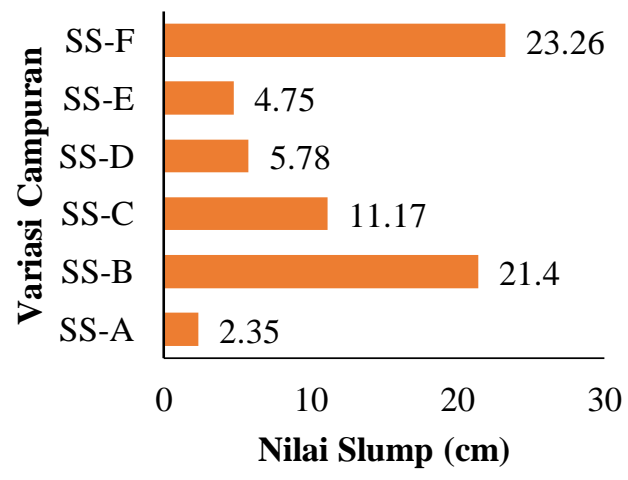

Gambar 1. Hasil pemeriksaan nilai slump

\section{Hasil Pemeriksaan Kuat Tekan}

Pemeriksaan kuat tekan beton awal dilakukan pada saat umur 3 hari, setelah itu 
dilakukan pengujian pada saat beton berumur 7 hari dan 28 hari. Tabel 6 menunjukkan hasil kuat tekan beton pada umur 3 hari SS-A sebesar $20.38 \mathrm{MPa}$ yang merupakan beton normal, hanya variasi SS-E memiliki kuat tekan lebih kecil dari beton normal yaitu sebesar 18,44 MPa, sedangkan variasi yang lainnya memiliki kuat tekan lebih tinggi dari beton normal dengan kuat tekan tertinggi pada variasi SS-F.

Pada umur 7 hari, beton normal memperoleh kuat tekan sebesar 25,68 MPa. Pada tahap ini, hanya SS-E yang masih tetap berata di bawah SS-A dari segi kekuatan nya sedangkan untuk variasi yang lain, masih berada di atas kekuatan beton normal. Sedangkan pada umur 28 hari beberapa variasi memiliki kekuatan di bawah beton normal (38,84 MPa) yaitu variasi SS-B sebesar 35,06 $\mathrm{MPa}$, SS-D dengan kuat tekan 37,38 MPa, variasi SS-E dengan kuat tekan $36,43 \mathrm{MPa}$ dan variasi SS-F dengan kuat tekan 38,23 $\mathrm{MPa}$. Sedangkan variasi SS-C merupakan variasi yang berada di atas kekuatan beton normal yaitu dengan nilai kuat tekan sebesar 39.94 MPa. Dari hasil ini dapat disimpulkan bahwa seluruh variasi tidak memiliki standar deviasi yang cukup besar, atau hasil yang diperoleh memiliki kekuatan yang hampir sama.

Tabel 6. Hasil kuat tekan beton rata-rata berdasarkan umur

\begin{tabular}{lccc}
\hline \multirow{2}{*}{ Kode } & \multicolumn{4}{c}{ Fc' Rata-Rata Berdasarkan } & Umur (MPa) \\
& 3 Hari & 7 Hari & 28 Hari \\
\hline SS-A & 20.38 & 25.68 & 38.84 \\
SS-B & 26.24 & 29.55 & 35.06 \\
SS-C & 26.21 & 35.59 & 39.94 \\
SS-D & 20.72 & 30.00 & 37.28 \\
SS-E & 18.44 & 22.02 & 36.43 \\
SS-F & 27.77 & 36.93 & 38.23 \\
\hline
\end{tabular}

Berdasarkan Gambar 2 yang menghubungkan antara masing-masing variasi dengan kuat tekan beton yang berumur 3 hari. Beton dengan kode SS-F memiliki nilai kuat tekan tertinggi yang kemudian di susul oleh variasi SS-B dan SS-C yang keseluruhannya memperoleh kuat tekan di atas $25 \mathrm{MPa}$. Sedangkan benda uji dengan kode SS-A dan SS-D memperoleh hasil kuat tekan beton di bawah 25 MPa namun masih di atas $20 \mathrm{MPa}$. Kuat tekan terkedil diperoleh oleh Sampel SS-E dengan hasil di bawah 20 $\mathrm{MPa}$, sampel SS-E merupakan variasi Sikafume 6\% san Sikament NN sebesar 0,5\%.

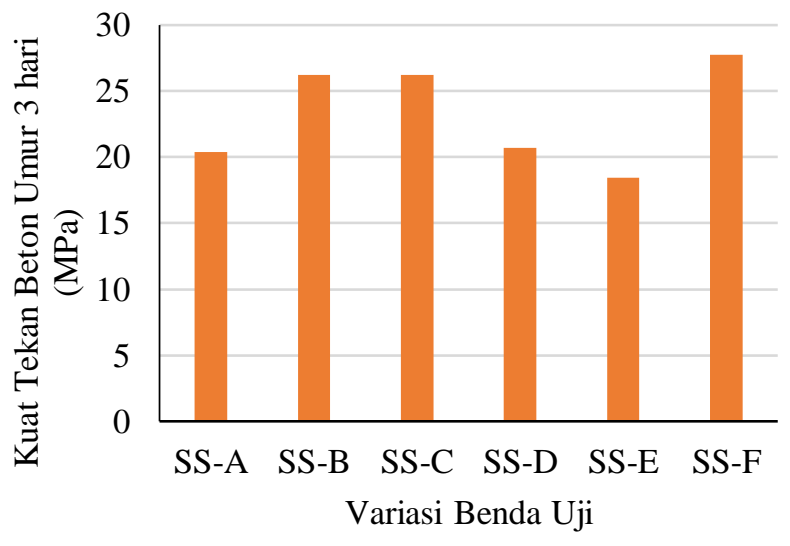

Gambar 2. Hasil kuat tekan beton umur 3 hari

Selain pada umur 3 hari, beton juga di uji pada umur 7 hari dan 28 hari seperti pada beton umumnya, berdasarkan Gambar 3 berikut ini, pada umur 28 hari kuat tekan beton menunjukkan hasil yang tidak berbeda jauh pada setiap variasi nya.

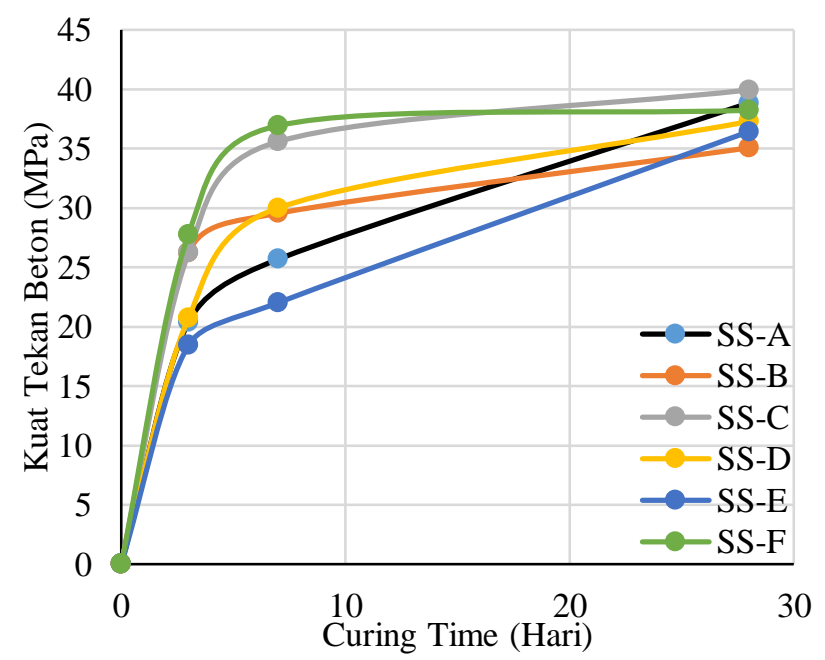

Gambar 3. Hubungan curing time dengan kuat tekan beton

Untuk mengetahui kadar optimum SikaFume dilakukan analisis regresi dari nilai kuat tekan beton pada umur 3 hari. Hasil analisis regresi dapat dilihat pada Gambar 4 yaitu berupa hubungan polynomial. Dari Gambar 4 kuat tekan beton semakin meningkat pada penggunaan SikaFume 0\% hingga $5 \%$, namun pada penggunaan SikaFume $>5 \%$ menunjukkan hasil kuat tekan yang semakin menurun. Dari hasil tersebut 
dapat diketahui bahwa kuat tekan tertinggi dapat tercapai pada penggunaan SikaFume sebesar 5\% dengan nilai kuat tekan tertinggi yaitu sebesar 26,83 $\mathrm{MPa}$, dan dapat ditarik kesimpulan bahwa kadar SikaFume optimum yang dapat digunakan untuk meningkatkan kuat tekan awal beton adalah 5\% dengan penambahan Sikament NN 1\%, analisis ini gunakan pada beton yang berumur 3 hari.

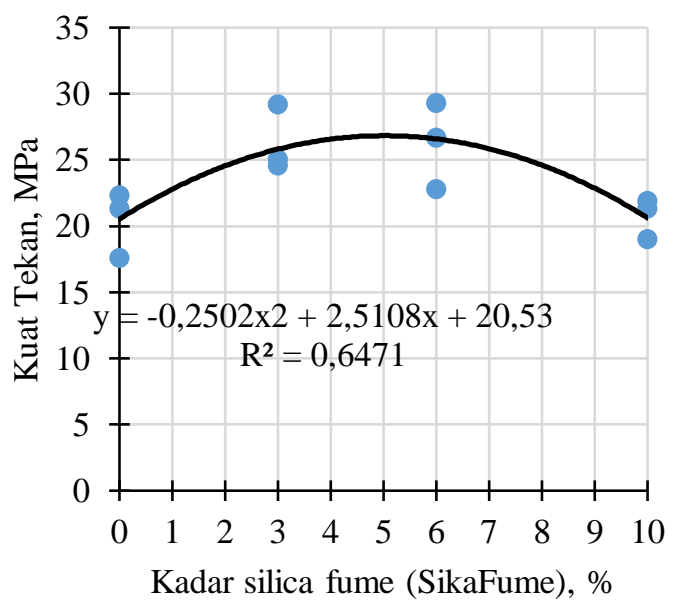

Gambar 4. Hubungan kadar SikaFume dengan kuat tekan beton umur 3 Hari

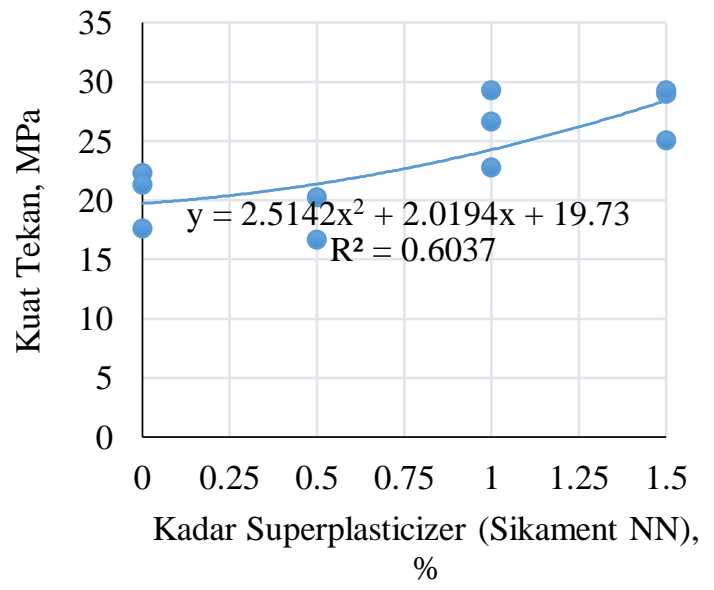

Gambar 5. Hubungan Superplastisizer dengan kuat tekan beton umur 3 hari

Analisis regresi polynomial dilakukan untuk mencari kadar optimum dari nilai kuat tekan beton pada umur 3 hari. Hasil analisis regresi dapat dilihat pada Gambar 5 di atas. Berdasarkan analisi polynomial. Berdasarkan Gambar 5 kuat tekan awal beton semakin meningkat pada penggunaan superplasticizer $0 \quad \%$ hingga $1,5 \%$. Berdasarkan hasil tersebut dapat diketahui bahwa kuat tekan awal tertinggi dapat tercapai pada penggunaan superplasticizer sebesar 1,5 $\%$ dengan nilai kuat tekan tertinggi yaitu sebesar 28,42 $\mathrm{MPa}$, dan dapat ditarik kesimpulan bahwa kadar superplasticizer yang dapat digunakan untuk meningkatkan kuat tekan awal beton dalam penelitian ini adalah $1,5 \%$ dengan penambahan silicafume $6 \%$.

\section{KESIMPULAN DAN SARAN Kesimpulan}

Penggunaan bahan tambah berupa silica fume dan superplasticizer pada campuran beton dengan kadar yang tepat dapat meningkatkan kualitas beton pada kekuatan tekan awalnya pada umur 3 hari maupun tingkat workability atau kelecakannya.

Berdasarkan pengujian dengansuperplasticizer $1 \%$ untuk semua variasi dan silicafume dengan variasi kadar $3 \%, 6 \%, 10 \%$ serta beton tanpa bahan tambah didapatkan kadar optimum silica fume (SikaFume) $5 \%$ dan superplasticizer (Sikament NN) $1 \%$ dengan kuat tekan 26,83 MPa.

Berdasarkan pengujian dengan superplasticizer $0,5 \%, 1 \%, 1,5 \%$ untuk semua variasi dan silicafume $6 \%$ serta beton tanpa bahan tambah didapatkan kadar optimum berada pada kadar superplasticizer $1,5 \%$ dan silicafume 6\% dengan kuat tekan awal beton 28,42 $\mathrm{MPa}$.

\section{Saran}

Saran pada penelitian ini sebaiknya mencoba melakukan pengujian pada umur beton 1 hari, sehingga dapat menghasilkan kuat tekan pada umur yang lebih cepat.

\section{DAFTAR PUSTAKA}

Badan Standarisasi Nasional. (1990). SK SNI 03-1974-1990: Metode Pengujian Kuat Tekan Beton. Jakarta: Departement Pekerjaan Umum.

Badan Standarisasi Nasional. (2000). SNI-032834-2000: Tata Cara Pembuatan Rencana Campuran Beton Normal. Jakarta: Departemen Pekerjaan Umum. 
Bhalla, N., Sharma, S., Sharma, S., Siddique, R. (2018). Monitoring Early Age Setting of Silica fume Concrete using Wave Propagation Techniques. Journal Construction and Building Materials, 153, 802-815.

Ikhsan, M.N., Prayuda, H., Saleh, F. (2016). Pengaruh Penambahan Pecahan Kaca Sebagai Bahan Pengganti Agregat Halus dan Penambahan Fiber Optik Terhadap Kuat Tekan Beton Serat. Jurnal Ilmiah Semesta Teknika, 19 (2), 148-156.

Karein, S. M. M., Ramezanianpour, A.A., Ebadi, T., Isapour, S. (2017). A New Approach for Application of Silica Fume in Concrete: Wet Granulation. Journal Construction and Building Materials, 157, 573-581.

Mazloom, M., Ramezanianpour, A.A., Brooks, J.J., (2004). Effect of Silica Fume on Mechanical Properties of High Strength Concrete. Cement and Concrete Composite, 26, 347-357.

Mulyono, T. (2003). Teknologi Beton. Yogyakarta: Andi Offset.

Pertiwi, H. (2011). Pengaruh Bahan Tambah Berbasis Gula Terhadap Kuat Tekan dan Modulus Elastisitas Beton. Tugas Akhir jurusan Teknik Sipil. Universitas Sebelas Maret. Surakarta.

Rostami, M., Behfarnia, K. (2017). The Effect of Cilica Fume on Durability of Alkali Activated Slag Concrete, Journal Construction and Building Materials, 134, 262-268.

Samekto, W., Rahmadiyanto, C. (2001). Teknologi Beton. Kanisius. Yogyakarta.

Shen, D., Shi, X., Zhu, S., Duan, X., Zhang, J. (2016). Relationship between Tensile Young's Modulus and Strength of Fly Ash High Strength Concrete at Early Age. Journal Construction and Building Materials, 123, 317-326.

Tjokrodimuljo, K. (2007). Teknologi Beton. Yogyakarta: Biro Penerbit Teknik Sipil Keluarga mahasiswa Teknik Sipil dan Lingkungan, Universitas Gadjah Mada. 